\title{
Denitrification in human dental plaque
}

\author{
Frank Schreiber ${ }^{1 *+}$, Peter Stief ${ }^{1+}$, Armin Gieseke ${ }^{1}$, Ines M Heisterkamp ${ }^{1}$, Willy Verstraete ${ }^{2}$, Dirk de Beer ${ }^{1}$, \\ Paul Stoodley ${ }^{3,4}$
}

\begin{abstract}
Background: Microbial denitrification is not considered important in human-associated microbial communities. Accordingly, metabolic investigations of the microbial biofilm communities of human dental plaque have focused on aerobic respiration and acid fermentation of carbohydrates, even though it is known that the oral habitat is constantly exposed to nitrate $\left(\mathrm{NO}_{3}{ }^{-}\right)$concentrations in the millimolar range and that dental plaque houses bacteria that can reduce this $\mathrm{NO}_{3}{ }^{-}$to nitrite $\left(\mathrm{NO}_{2}{ }^{-}\right)$.

Results: We show that dental plaque mediates denitrification of $\mathrm{NO}_{3}^{-}$to nitric oxide ( $\mathrm{NO}$ ), nitrous oxide $\left(\mathrm{N}_{2} \mathrm{O}\right)$, and dinitrogen $\left(\mathrm{N}_{2}\right)$ using microsensor measurements, ${ }^{15} \mathrm{~N}$ isotopic labelling and molecular detection of denitrification genes. In vivo $\mathrm{N}_{2} \mathrm{O}$ accumulation rates in the mouth depended on the presence of dental plaque and on salivary $\mathrm{NO}_{3}{ }^{-}$concentrations. $\mathrm{NO}$ and $\mathrm{N}_{2} \mathrm{O}$ production by denitrification occurred under aerobic conditions and was regulated by plaque $\mathrm{pH}$.

Conclusions: Increases of NO concentrations were in the range of effective concentrations for NO signalling to human host cells and, thus, may locally affect blood flow, signalling between nerves and inflammatory processes in the gum. This is specifically significant for the understanding of periodontal diseases, where NO has been shown to play a key role, but where gingival cells are believed to be the only source of NO. More generally, this study establishes denitrification by human-associated microbial communities as a significant metabolic pathway which, due to concurrent $\mathrm{NO}$ formation, provides a basis for symbiotic interactions.
\end{abstract}

\section{Background}

The human body is naturally colonised by a diverse array of micro-organisms whose metabolic activity is important for human physiology and health [1]. Most studies that assess the functional potentials and controls of these complex communities rely on: (i) the characterisation of individual isolates or enrichments, (ii) quantification of micro-organisms that are thought to mediate a certain process, or (iii) metagenomic analysis of a certain body region. Established methods of microbial ecology that allow the direct measurement of metabolic conversions in natural microbial samples from humans under different experimental conditions, such as incubation with isotopically-labelled substrates, dye probes for specific compounds combined with microscopy or electrochemical microsensors, are rarely reported. However, different microbial pathways, including fermentation,

\footnotetext{
* Correspondence: fschreib@mpi-bremen.de

† Contributed equally

'Microsensor Research Group, Max-Planck-Institute for Marine Microbiology, Bremen, Germany
}

sulfate reduction, methanogenesis and acetogenesis [2-5], have been proposed to occur in humans. Surprisingly, denitrification (the respiratory reduction of nitrate $\left(\mathrm{NO}_{3}{ }^{-}\right)$or nitrite $\left(\mathrm{NO}_{2}{ }^{-}\right)$via nitric oxide (NO) to nitrous oxide $\left(\mathrm{N}_{2} \mathrm{O}\right)$ or dinitrogen $\left.\left(\mathrm{N}_{2}\right)[6]\right)$ is believed to be insignificant in human-associated microbial communities [7], even though $\mathrm{NO}_{3}{ }^{-}$and $\mathrm{NO}_{2}{ }^{-}$co-occur in significant concentrations with micro-organisms in various body regions, such as the human oral cavity [8].

Denitrification is performed by facultative anaerobic micro-organisms and is coupled to the oxidation of reduced organic carbon or reduced inorganic compounds, such as ferrous iron, hydrogen sulfide or hydrogen [6,9]. The reductive sequence $\left(\mathrm{NO}_{3}{ }^{-}>\mathrm{NO}_{2}{ }^{-}>\mathrm{NO}\right.$ $>\mathrm{N}_{2} \mathrm{O}>\mathrm{N}_{2}$ ) of denitrification is mediated by periplasmic and membrane-bound enzymes specific for each step. The most important genes for the detection of denitrification in complex microbial samples are narG for $\mathrm{NO}_{3}{ }^{-}$reductase, nirS and nirK for $\mathrm{NO}_{2}{ }^{-}$reductases, qnorB or cnorB for $\mathrm{NO}$ reductases, and nos $Z$ for $\mathrm{N}_{2} \mathrm{O}$ reductase. Denitrifying bacteria release $\mathrm{NO}$ or $\mathrm{N}_{2} \mathrm{O}$ as 
intermediates during metabolic activity in pure culture $[10,11]$ and in complex microbial communities, such as soils [12], nitrogen cycling biofilms [13] and ingested bacteria within different invertebrates guts [14,15].

Notably, human saliva contains $\mathrm{NO}_{3}{ }^{-}$concentrations in the millimolar range, because dietary $\mathrm{NO}_{3}{ }^{-}$is concentrated in salivary glands after it is absorbed from the intestine into the blood [8]. Thus, the human-associated microbial biofilm community of dental plaque and bacteria that cover other oral surfaces are exposed to $\mathrm{NO}_{3}{ }^{-}$. However, investigations of plaque metabolism have focused on aerobic respiration and acid fermentation of carbohydrates [16]. Experiments with rat tongues as well as tooth and other surfaces in the human mouth have shown that salivary $\mathrm{NO}_{3}{ }^{-}$can be converted by oral micro-organisms to $\mathrm{NO}_{2}{ }^{-}$, explaining the presence of $\mathrm{NO}_{2}{ }^{-}$in addition to $\mathrm{NO}_{3}{ }^{-}$in saliva $[17,18]$. Detection of $\mathrm{NO}$ in air incubated in the human mouth has led to the hypothesis that bacterially-derived salivary $\mathrm{NO}_{2}{ }^{-}$is chemically reduced to $\mathrm{NO}$ in acidic microenvironments in the oral cavity $[18,19]$. The underlying processes have never been directly demonstrated because NO could not be measured in dental biofilms over relevant spatial scales. Therefore, other investigators considered $\mathrm{NO}_{2}{ }^{-}$in human saliva a stable oxidation product of NO synthasederived NO that is produced by gingival cells to regulate the gum immune and vascular systems [20,21].

Due to the possible formation of NO, plaque nitrogen metabolism might be important to dental health. Dental plaque causes periodontal diseases and dental caries, affecting almost every human being [22,23]. As an inflammatory disorder of gum tissue surrounding the teeth, periodontal diseases might be especially affected by nitrogen metabolism of dental plaque, if NO is generated as a side product at the gum-plaque interface. NO plays a complex, but not well understood role in periodontal diseases [24,25]. NO, at low concentrations, is an important signalling molecule that coordinates functions of immune system cells that are involved in inflammatory processes [26]. Bacterial lipopolysaccharides stimulate production of proinflammatory cytokines, which induce production of high, cytotoxic NO concentrations by certain immune system cells. Furthermore, high NO levels during inflammation induce expression of matrix metalloproteinases in neutrophiles, which mediate soft tissue degradation [27].

Besides its potential importance to dental health, oral nitrogen metabolism is important for human physiology [8]. The formation of $\mathrm{NO}_{2}{ }^{-}$as a denitrification intermediate by oral micro-organisms leads to chemical conversion of $\mathrm{NO}_{2}{ }^{-}$to $\mathrm{NO}$ in the acidic stomach, acting as an antimicrobial agent against pathogenic bacteria and stimulating gastric blood flow. Moreover, $\mathrm{NO}_{2}{ }^{-}$is absorbed into plasma, where it serves as a NO source for the regulation of vasodilatation under hypoxic conditions [8]. It is still unclear whether microbial nitrogen metabolism in human dental plaque is significant in comparison to other oral surfaces.

In the present study, we hypothesise that dental plaque represents a habitat for microbial denitrification in humans, driving the biological conversion of salivary $\mathrm{NO}_{3}{ }^{-}$to the denitrification intermediates $\mathrm{NO}$ and $\mathrm{N}_{2} \mathrm{O}$, and to the final product $\mathrm{N}_{2}$. We use direct microbial ecology methods, including a recently developed NO microsensor [28], to demonstrate in situ NO formation during denitrification in dental plaque and to show that $\mathrm{NO}$ is formed at concentrations that are significant for signalling to host tissue. In addition, we aim to show the in vivo significance of plaque denitrification for the formation of denitrification intermediates by correlating the oral accumulation of $\mathrm{N}_{2} \mathrm{O}$ in humans to salivary $\mathrm{NO}_{3}{ }^{-} / \mathrm{NO}_{2}{ }^{-}$concentrations and to the presence of plaque.

\section{Results}

\section{Dental plaque mediates aerobic denitrification}

Dental plaque converted $\mathrm{NO}_{3}{ }^{-}$to $\mathrm{N}_{2}$ by denitrification. This was shown by ${ }^{30} \mathrm{~N}_{2}$ formation from ${ }^{15} \mathrm{NO}_{3}{ }^{-}$during incubation of dispersed dental plaque (Figure 1a). The occurrence of complete denitrification in dental biofilms was corroborated by polymerase chain reaction (PCR) detection of all genes $\left(\mathrm{NO}_{3}{ }^{-}\right.$reductase, $\mathrm{NO}_{2}{ }^{-}$reductase, $\mathrm{NO}$ reductase, $\mathrm{N}_{2} \mathrm{O}$ reductase) that are necessary for the respiratory reduction of $\mathrm{NO}_{3}{ }^{-}$to $\mathrm{N}_{2}$ (Table 1 ). Genes for respiratory $\mathrm{NO}$ reductases were restricted to the presence of the quinol-dependent type (qnor $B$ ), but not of the cytochrome $c$-dependent type (cnor $B)$.

Two lines of evidence suggested that denitrification in dental biofilms occurred under aerobic conditions. First, we observed ${ }^{30} \mathrm{~N}_{2}$ production from plaque that was suspended in air-saturated medium amended with $50 \mu \mathrm{M}$ ${ }^{15} \mathrm{NO}_{3}^{-}$(Figure 1a). $\mathrm{O}_{2}$ measurements in this medium showed that aerobic heterotrophic respiration did not lead to anoxic conditions during the incubation period (Figure 1b). Second, microsensor measurements showed that $\mathrm{NO}_{3}{ }^{-}$was consumed in the presence of $\mathrm{O}_{2}$ and that also the denitrification intermediates $\mathrm{NO}$ and $\mathrm{N}_{2} \mathrm{O}$ were formed in the presence of $\mathrm{O}_{2}$ (Figure 2a-d). At this low $\mathrm{NO}_{3}{ }^{-}$concentration it is conceivable that all $\mathrm{NO}_{3}{ }^{-}$was used for assimilation into biomass, and was thus not available for respiratory denitrification. However, in this plaque sample $\mathrm{NO}_{3}{ }^{-}$was not completely consumed (that is, $\mathrm{NO}_{3}{ }^{-}$was not limiting) when present at a concentration of $50 \mu \mathrm{M} \mathrm{NO}_{3}{ }^{-}$(Figure 2a). Thus, $\mathrm{NO}_{3}{ }^{-}$assimilation and denitrification must have been already present at their maximum capacity at $50 \mu \mathrm{M} \mathrm{NO}_{3}^{-}$. Further increases of the $\mathrm{NO}_{3}{ }^{-}$concentration to $760 \mu \mathrm{M}$ will most likely not change the contribution of both 

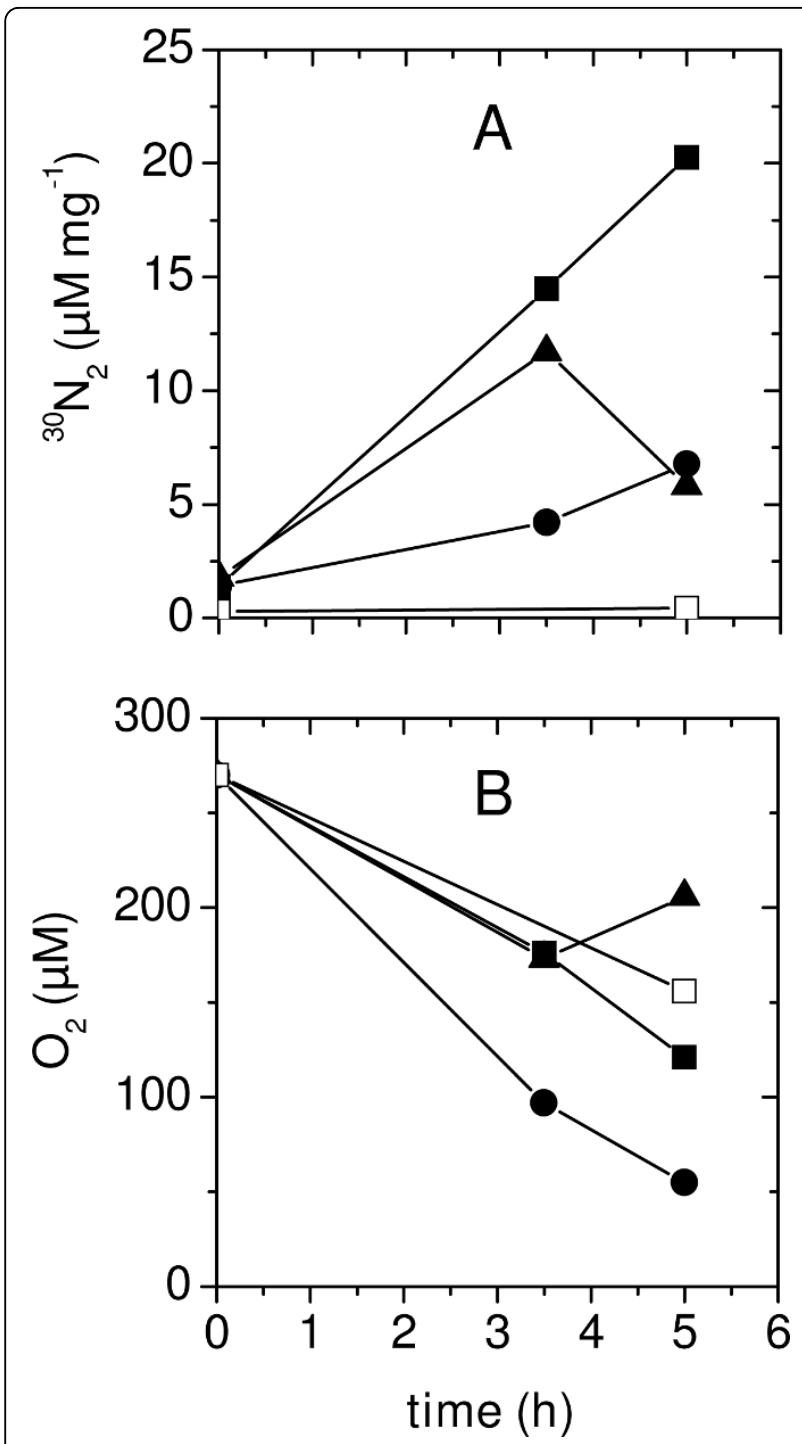

Figure 1 Denitrification in dental plaque. Dental plaque of three individuals was suspended in aerobic mineral medium buffered at $\mathrm{pH} 7.2$ containing $2 \%$ sucrose and $50 \mu \mathrm{M} \mathrm{Na}{ }^{15} \mathrm{NO}_{3}$. Formation of (a) ${ }^{30} \mathrm{~N}_{2}$ (in $\mu \mathrm{M} / \mathrm{mg}$ protein) and (b) apparent $\mathrm{O}_{2}$ concentrations (in $\mu \mathrm{M})$ were measured in a time series experiment. Each symbol type represents ${ }^{30} \mathrm{~N}_{2}$ and $\mathrm{O}_{2}$ measurements of dental plaque incubations from one individual. Control measurements were done in the absence of $\mathrm{Na}^{15} \mathrm{NO}_{3}$ (open symbols).

pathways to the total $\mathrm{NO}_{3}{ }^{-}$uptake. In turn, the biofilm remained oxic when subjected to $760 \mu \mathrm{M} \mathrm{NO}_{3}{ }^{-}$and produced the denitrification intermediates $\mathrm{NO}$ and $\mathrm{N}_{2} \mathrm{O}$ (Figure 2f-h) indicating that aerobic denitrification was also active at high $\mathrm{NO}_{3}{ }^{-}$concentrations.

\section{Chemical and biological $\mathrm{NO}$ and $\mathrm{N}_{2} \mathrm{O}$ formation during plaque denitrification is $\mathrm{pH}$ dependent}

$\mathrm{NO}_{3}{ }^{-}$was the source for $\mathrm{NO}$ and $\mathrm{N}_{2} \mathrm{O}$ in dental biofilms. This was shown by $\mathrm{NO}$ and $\mathrm{N}_{2} \mathrm{O}$ formation being
Table 1 Denitrification genes in dental biofilms of five volunteers

\begin{tabular}{|c|c|c|c|c|c|c|}
\hline \multirow[t]{2}{*}{ Volunteer } & \multirow{2}{*}{$\begin{array}{l}\mathrm{NO}_{3}{ }^{-} \\
\text {reductase } \\
\text { narG }\end{array}$} & \multicolumn{2}{|c|}{$\begin{array}{l}\mathrm{NO}_{2}^{-} \\
\text {reductase }\end{array}$} & \multicolumn{2}{|c|}{$\begin{array}{l}\text { NO } \\
\text { reductase }\end{array}$} & \multirow{2}{*}{$\begin{array}{l}\mathrm{N}_{2} \mathrm{O} \\
\text { reductase } \\
\text { nos } Z\end{array}$} \\
\hline & & nirs & nirK & CnorB & qnorB & \\
\hline A & + & + & + & - & + & + \\
\hline$B$ & + & + & + & - & + & + \\
\hline $\mathrm{C}$ & + & + & + & - & + & + \\
\hline $\mathrm{D}$ & + & - & + & - & + & + \\
\hline$E$ & + & NA & NA & - & + & NA \\
\hline
\end{tabular}

Results are based on detection of a PCR product with the expected size or on the additional analysis of the sequence of the PCR product.

$\mathrm{NA}=$ not analysed

restricted to the presence of $\mathrm{NO}_{3}{ }^{-}$(Figure 2g, h). NO formation in dental biofilms was mediated by both biological $\mathrm{NO}_{2}{ }^{-}$reduction and presumably acidic decomposition of $\mathrm{NO}_{2}{ }^{-}$. Biological $\mathrm{NO}_{2}{ }^{-}$reduction was the sole process that produced $\mathrm{NO}$ when the medium was buffered at approximately $\mathrm{pH}$ 7. In non-buffered medium, bacterial activity decreased biofilm $\mathrm{pH}<5$ (Figure 2e) and depth-averaged $\mathrm{NO}$ concentrations increased from 0.08 to $0.15 \mu \mathrm{M}$ (Figure 2g). Titration of $50 \mu \mathrm{M} \mathrm{NO}_{2}{ }^{-}$to a buffer at $\mathrm{pH} 4.7$ showed that acidic decomposition of $\mathrm{NO}_{2}{ }^{-}$caused chemical formation of approximately 0.05 $\mu \mathrm{M}$ NO (Figure 3), which is in the same range than the observed increase in the biofilm at $\mathrm{pH}<5$. It is already known that plaque can form $\mathrm{NO}_{2}{ }^{-}$by $\mathrm{NO}_{3}{ }^{-}$reduction [17]. $\mathrm{NO}_{2}^{-}$can also naturally accumulate in saliva to concentrations of $50 \mu \mathrm{M}$ and higher (data not shown, and [18]). Taken together, this suggests that acidic decomposition of $\mathrm{NO}_{2}{ }^{-}$contributes to $\mathrm{NO}$ formation at low plaque $\mathrm{pH}$ levels, while biological NO formation may still occur in parallel.

The absolute increase of NO due to acidic conditions was small from the perspective of the metabolic homeostasis of denitrification. This was evident because depth-averaged increases of $\mathrm{N}_{2} \mathrm{O}$, the product of $\mathrm{NO}$ reduction, were approximately two orders of magnitude higher than those of NO concentrations under acidic conditions. This suggests that biofilm bacteria efficiently convert most $\mathrm{NO}$ to $\mathrm{N}_{2} \mathrm{O}$ and thereby keep the steadystate concentration of cytotoxic NO low, as has been also observed in environmental biofilms [13].

\section{NO formation decreases $\mathrm{O}_{2}$ uptake of dental plaque}

Oxygen uptake in the presence of $\mathrm{NO}_{3}{ }^{-}$was higher at neutral $\mathrm{pH}$ than under acidic conditions (Figure 2e, f). The $\mathrm{O}_{2}$ profiles showed that the flux of $\mathrm{O}_{2}$ decreased by $50 \%$, namely from $-105 \mathrm{nmol} / \mathrm{cm}^{2} / \mathrm{h}$ under buffered conditions to $-43 \mathrm{nmol} / \mathrm{cm}^{2} / \mathrm{h}$ under non-buffered conditions. Acidic $\mathrm{pH}$ alone did not lead to reduced $\mathrm{O}_{2}$ uptake when $\mathrm{NO}_{3}{ }^{-}$was absent, as the $\mathrm{O}_{2}$ flux was 


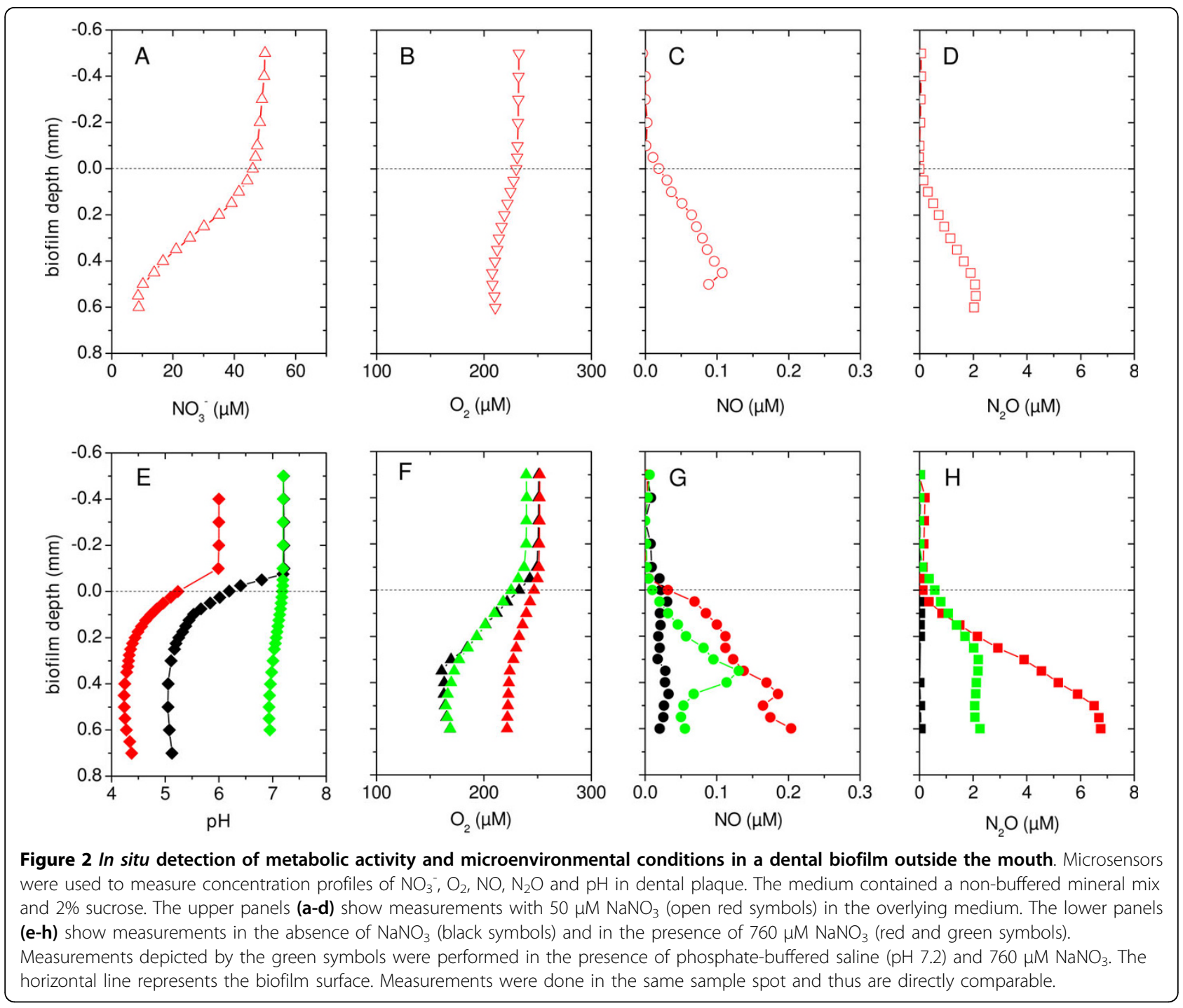

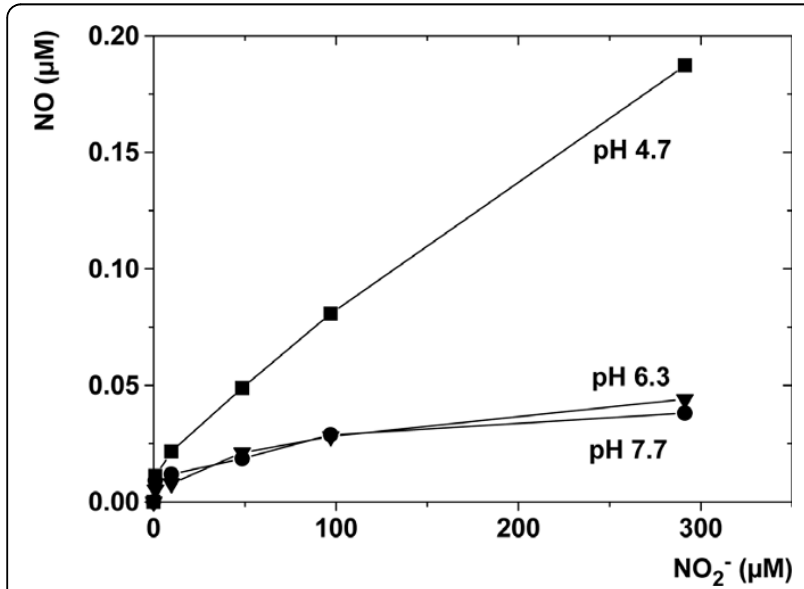

Figure $\mathbf{3}$ Chemical formation of $\mathrm{NO}$ by acidic decomposition of $\mathrm{NO}_{2}{ }^{-}$. NO formation was measured with a $\mathrm{NO}$ microsensor during titration of increasing $\mathrm{NO}_{2}{ }^{-}$concentrations in different solutions of phosphate-buffered saline at varying $\mathrm{pH}$.
$-143 \mathrm{nmol} / \mathrm{cm}^{2} / \mathrm{h}$. Decreased bacterial $\mathrm{O}_{2}$ consumption might result from direct toxic effects of the highest NO concentration ( 0.15 to $0.2 \mu \mathrm{M})$, such as binding of $\mathrm{NO}$ to terminal, respiratory $\mathrm{O}_{2}$ reductases [29]. However, the absolute increase from 0.08 to $0.2 \mu \mathrm{M}$ may not affect respiration as concentrations above $0.8 \mu \mathrm{M}$ were previously shown to be necessary to inhibit $\mathrm{O}_{2}$ reduction in Escherichia coli [30]. In addition, instead of facilitating $\mathrm{O}_{2}$ reduction, a small fraction of electrons might be used preferentially for detoxification of $\mathrm{NO}$ by reduction to $\mathrm{N}_{2} \mathrm{O}$, contributing to increased $\mathrm{N}_{2} \mathrm{O}$ concentrations and inhibited $\mathrm{O}_{2}$ uptake (Figure 2f, h).

\section{$\mathrm{N}_{2} \mathrm{O}$ production in the human mouth is dependent on} salivary $\mathrm{NO}_{3}{ }^{-}$and on the presence of dental plaque We incubated air in the human mouth ('mouth air') and measured the rate of $\mathrm{N}_{2} \mathrm{O}$ accumulation to quantify the 
in vivo significance of denitrification in the oral habitat. We related $\mathrm{N}_{2} \mathrm{O}$ accumulation in mouth air to the presence of dental biofilms and salivary $\mathrm{NO}_{3}{ }^{-} / \mathrm{NO}_{2}{ }^{-}$concentrations (Figure 4). $\mathrm{N}_{2} \mathrm{O}$ accumulation in the presence of dental plaque varied strongly between the subjects and ranged from 11 to $443 \mathrm{nmol} / \mathrm{h} . \mathrm{N}_{2} \mathrm{O}$ accumulation between subjects increased with increasing salivary $\mathrm{NO}_{3}{ }^{-} / \mathrm{NO}_{2}{ }^{-}$concentrations (Figure 4a). Drinking $200 \mathrm{ml}$ beetroot juice that contained $12 \mathrm{mmol} / \mathrm{NO}_{3}{ }^{-}$increased the salivary $\mathrm{NO}_{3}{ }^{-} / \mathrm{NO}_{2}{ }^{-}$concentrations, which led to an increase of between 3.8 and 9.1 fold in the rate of oral $\mathrm{N}_{2} \mathrm{O}$ accumulation.

Dental biofilms were the main sites of $\mathrm{N}_{2} \mathrm{O}$ production in the human mouth. This was evident because the combined application of ordinary tooth brushing with an antiseptic mouthwash decreased oral $\mathrm{N}_{2} \mathrm{O}$ accumulation rate by $82 \%$, while tooth brushing alone decreased the rate of oral $\mathrm{N}_{2} \mathrm{O}$ accumulation by $62 \%$ (Figure $4 \mathrm{~b}$ ).

\section{Discussion}

Our data show unambiguously that denitrification is a relevant process in a human associated microbial community. Until now, it was assumed that complete $\mathrm{NO}_{3}{ }^{-}$ reduction in humans is restricted to the dissimilatory nitrate reduction to ammonium (DNRA), because most bacterial isolates from humans are able to perform this reaction [7,31]. DNRA is known to be a strictly anaerobic process that is favoured over denitrification in anaerobic, reduced environments [32]. Accordingly, DNRA might prevail in the reduced, anaerobic environment of the human gut, while denitrification is present in the more oxidised dental plaque. In turn, it is conceivable that DNRA is present in plaque that is recalcitrant to removal and thus, constantly anoxic and more reduced. Theoretically, in such biofilms $\mathrm{NO}_{2}^{-}$reduction might be coupled to the anaerobic oxidation of ammonium (anammox) (Figure 5, black dotted lines), especially if protein degradation of host tissue or DNRA could provide a source for ammonium, as has been reported in marine open water habitats [33]. Denitrification, however, might be present in other oxidised environments in humans where bacteria and $\mathrm{NO}_{3}{ }^{-}$co-occur. For example, $\mathrm{NO}_{3}{ }^{-}$ is also present in other body fluids than saliva that may provide a rather oxidised environment (for example, blood 20 to $40 \mu \mathrm{M}$ and urine approximately $500 \mu \mathrm{M}$ ) [8]. Thus, denitrification might be relevant in microbial biofilms that are associated to other diseased or healthy sites, such as cystic fibrosis lungs, otitis media ears, implants, catheters and vaginal mucosa [34].

Denitrification and DNRA are fundamentally different with respect to their final products, metabolic controls and released intermediates resulting in different effects on host physiology. Ammonium, the final product of DNRA, is available to host cells and associated microbes as a form of fixed nitrogen. Moreover, DNRA in humans may accumulate ammonium to detrimental concentrations [35]. In contrast, $\mathrm{N}_{2}$, the final product of denitrification, represents a loss of fixed nitrogen from the host and does not affect human cells. Furthermore, production of the signalling molecule NO by microbial denitrification might shape the interactions between the host cells and their associated microbial community.

Interestingly, denitrification in dental biofilms occurred under aerobic conditions. This shows that dental plaque does not necessarily have to display anoxic microsites for denitrification to occur. The ability to denitrify in the presence of $\mathrm{O}_{2}$ has been observed for isolated bacterial strains and occasionally for microbial communities [36,37]. Aerobic denitrification guarantees a stable electron accepting process in a $\mathrm{NO}_{3}{ }^{-}$-rich habitat exposed to frequent fluctuations in $\mathrm{O}_{2}$ concentration without energy-demanding expression of new enzyme systems [38]. This may perfectly apply to the oral habitat that is characterised by high salivary $\mathrm{NO}_{3}{ }^{-}$and potentially fluctuating $\mathrm{O}_{2}$ concentrations in the mouth.

Despite the microbial diversity of dental biofilms [16], we could only detect genes for respiratory NO reductases of the quinol-dependent type (qnorB), but not of the cytochrome $c$-dependent type (cnor $B$ ). Interestingly, genes that code for $\mathrm{qNorB}$ are also found in non-denitrifying, pathogenic bacteria, where it contributes to NO detoxification, instead of respiratory electron transport [39]. Apparently, respiratory NO reduction is exclusively mediated by qNorB in the investigated dental biofilms. Additionally, qNorB might be used as a protective enzyme against toxic NO derived from host cells, acidic decomposition of $\mathrm{NO}_{2}{ }^{-}$and other biofilm bacteria.

Our results allowed us to formulate a mechanistic model for nitrogen conversions in dental plaque (Figure 5). First, reduction of salivary $\mathrm{NO}_{3}{ }^{-}$leads to the formation of $\mathrm{NO}_{2}^{-}$[17], which is further denitrified to form the intermediates $\mathrm{NO}$ and $\mathrm{N}_{2} \mathrm{O}$ and finally $\mathrm{N}_{2}$ (Figure 5 , green lines). The mechanistic model involves a $\mathrm{pH}$-controlled chemical conversion step from $\mathrm{NO}_{2}^{-}$to $\mathrm{NO}$ in addition to the biological conversion step (Figure 5, red line). The chemical conversion of $\mathrm{NO}_{2}{ }^{-}$to $\mathrm{NO}$ occurs if acid fermentation decreases plaque $\mathrm{pH}<5$. High turnover of NO under acidic conditions leads to decreased $\mathrm{O}_{2}$ uptake in dental biofilms. This argues toward an NO-mediated metabolic coupling of different microbial activities in dental plaque. Moreover, bacteria respond to $\mathrm{NO}$ as a signalling molecule. Specifically, $\mathrm{NO}$ is involved in the dispersal of bacteria from biofilms [40]. Together this makes NO a possible bacterially-derived factor that balances the development of a natural dental plaque community. Thus, NO might be an important factor from the perspective of the 'ecological plaque hypothesis', which states that environmental factors (for 


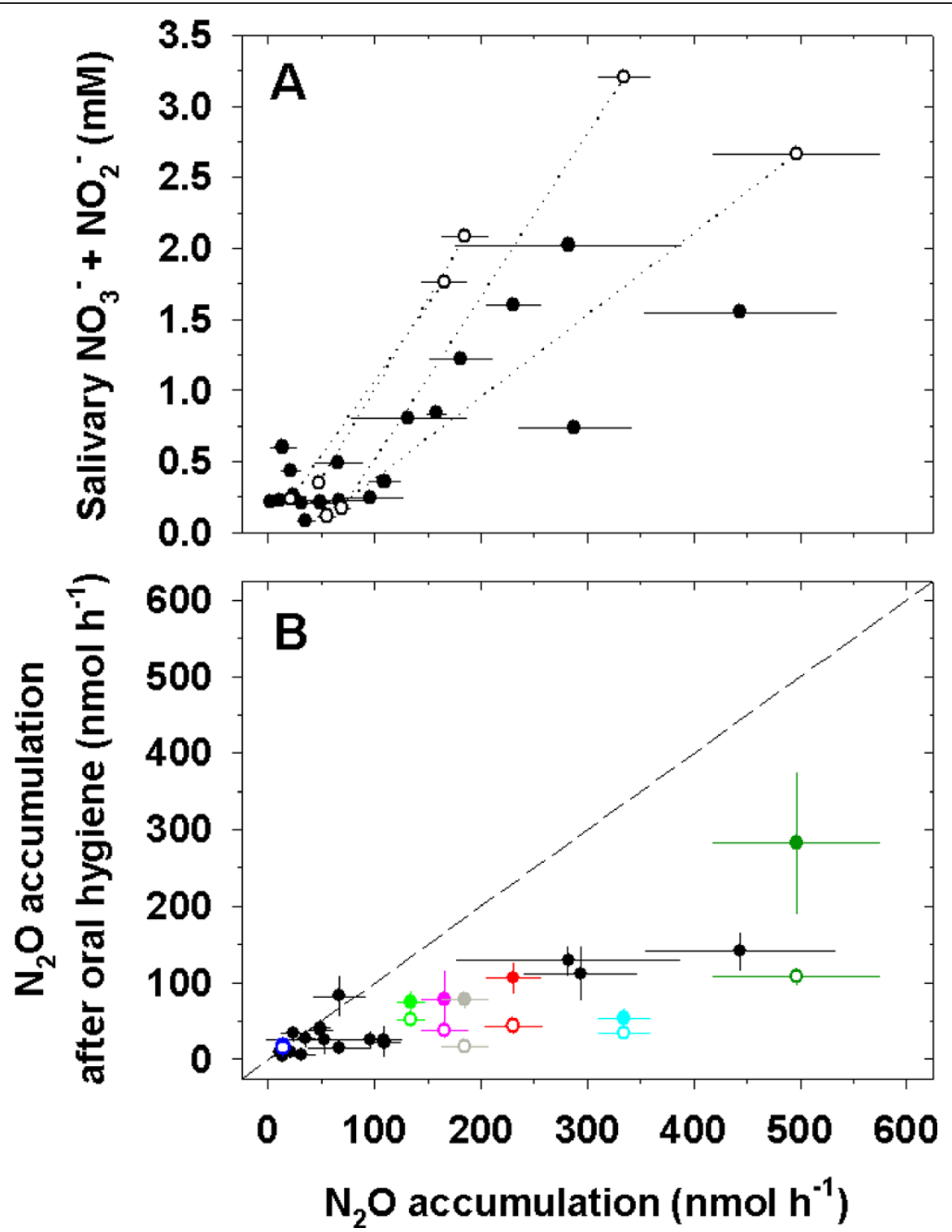

Figure $4 \mathrm{~N}_{2} \mathrm{O}$ formation in the human mouth is dependent on salivary $\mathrm{NO}_{2}{ }^{-} / \mathrm{NO}_{3}{ }^{-}$concentrations and the presence of dental plaque. (a) Correlation of oral $\mathrm{N}_{2} \mathrm{O}$ production and salivary $\mathrm{NO}_{2}{ }^{-} / \mathrm{NO}_{3}{ }^{-}$concentration in 15 volunteers with unbrushed teeth. Each data point represents the rate of oral $\mathrm{N}_{2} \mathrm{O}$ accumulation of one individual on a certain day (black circles). Some volunteers were sampled on more than 1 day resulting in 19 data points in total. Four volunteers were additionally sampled before and after drinking $\mathrm{NO}_{3}{ }^{-}$-rich beetroot juice to increase salivary $\mathrm{NO}_{2}{ }^{-} / \mathrm{NO}_{3}{ }^{-}$concentration and oral $\mathrm{N}_{2} \mathrm{O}$ accumulation (white circles connected by dotted line). (b) Effect of oral hygiene on $\mathrm{N}_{2} \mathrm{O}$ accumulation rate in the mouth. Oral $\mathrm{N}_{2} \mathrm{O}$ accumulation rate of individuals before tooth brushing plotted against the $\mathrm{N}_{2} \mathrm{O}$ accumulation rate after tooth brushing (closed circles). In six individuals an antiseptic mouth rinse that affects bacteria in the entire oral cavity was applied after tooth brushing (open circles, each of the six individuals is represented by a unique colour). For example, an individual (dark green) with an oral $\mathrm{N}_{2} \mathrm{O}$ accumulation rate of $500 \mathrm{nmol} / \mathrm{h}$ reduced the rate to $290 \mathrm{nmol} / \mathrm{h}$ by tooth brushing. Subsequent application of a mouth rinse resulted in a rate of $110 \mathrm{nmol} / \mathrm{h}$. The dashed line corresponds to the absence of an effect of oral hygiene on the oral $\mathrm{N}_{2} \mathrm{O}$ accumulation. The error bars indicate the standard error of five replicate measurements of the oral $\mathrm{N}_{2} \mathrm{O}$ accumulation rate.

example, $\mathrm{pH}$ and salivary $\mathrm{NO}_{3}{ }^{-}$) in the mouth determine if the dental plaque microbial community is dominated by either health-sustaining or disease-causing microorganisms [41].

Human cells can produce NO from arginine by NO synthase activity and respond to $\mathrm{NO}$ as a signal molecule produced by other cells [26]. In gingival tissue, $\mathrm{NO}$ is known to be involved in blood pressure regulation and in inflammatory processes, such as those in periodontal diseases [24,27]. Under acidic conditions, the depth-averaged $\mathrm{NO}$ concentration in dental plaque increased from 0.08 to $0.15 \mu \mathrm{M}$ (Figure $2 \mathrm{~g}$ ), which is in 
e.g. antimicrobial activity and hypoxic vasodilatation (reviewed in Lundberg et al., 2008)

\section{$\mathrm{NO} \longleftarrow \mathrm{NO}_{3}^{-}$}

transport into stomach and blood; reduction by low pH or human enzymes nitrate reduction (Doel et al., 2005)

narG
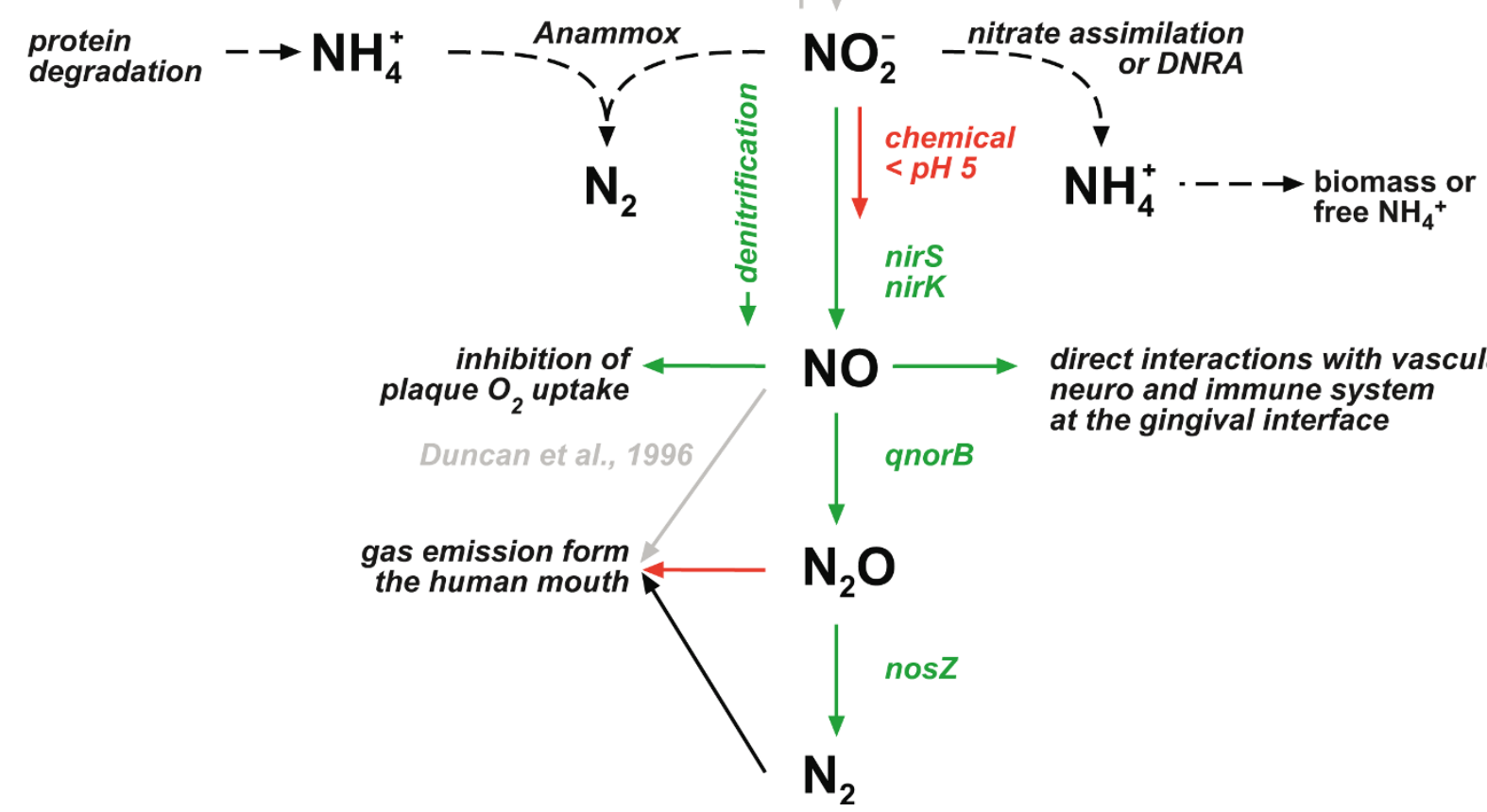

direct interactions with vascular, neuro and immune system at the gingival interface

Figure 5 Microbial conversions of salivary $\mathrm{NO}_{3}{ }^{-}$in human dental plaque and its possible consequences. Grey lines show pathways that have been reported previously. Dotted lines show potential pathways that have not been reported to occur in dental plaque in this or other studies. Coloured lines show pathways that are suggested to occur by this study. Green lines show biologically-mediated pathways and red lines show chemically-mediated or physically-mediated pathways. Genes encoding for enzymes that mediate individual steps of denitrification are depicted if detected in dental biofilms via polymerase chain reaction (PCR). Genes of the cytochrome $c$-dependent NO reductase (cNorB) were not detected. Anammox = anaerobic oxidation of ammonium; DNRA = dissimilatory nitrate reduction to ammonium.

a physiological effective range $[42,43]$ for local blood pressure regulation, neurosignalling events and immune system modulation in tissues close to plaque. Hence, we hypothesise that $\mathrm{pH}$ fluctuations and plaque denitrification may locally affect blood flow, signalling between nerves, and inflammatory processes in the gum by modulating the concentration of NO (Figure 5, green line). NO-mediated interactions will be different in cariogenic as compared to periodontal plaque, because both are characterised by distinct $\mathrm{pH}$ regimes [41]. While low $\mathrm{pH}$ levels in cariogenic plaque may induce chemical NO formation leading to high NO concentrations, NO formation in periodontal plaque will be restricted to microbial processes, because it is characterised by $\mathrm{pH}$ levels $>7$. As discussed above, microbial denitrification might be relevant in other healthy and diseased sites of the body. Thus more generally, microbial denitrification might be considered an alternative route for NO formation in humans and provides a basis for symbiotic interactions between human-associated microbes and adjacent host cells.

The presence of dental plaque caused accumulation of $\mathrm{N}_{2} \mathrm{O}$, as an intermediate of denitrification, in mouth air depending on salivary $\mathrm{NO}_{3}{ }^{-}$concentrations. This demonstrates that denitrification occurs in vivo and that dietary $\mathrm{NO}_{3}{ }^{-}$-uptake influences plaque denitrification. The average rate of oral $\mathrm{N}_{2} \mathrm{O}$ emission from 15 volunteers with unbrushed teeth and non-manipulated salivary $\mathrm{NO}_{3}{ }^{-} / \mathrm{NO}_{2}{ }^{-}$concentrations was $80 \mathrm{nmol} / \mathrm{h}$. While earlier investigations of the breath air of human beings revealed $\mathrm{N}_{2} \mathrm{O}$ concentrations above the ambient atmospheric level [44-46], our study presents the first oralassociated emission rates of this greenhouse gas [47] by humans. Extrapolating our data to the world population of currently 6.7 billion people, oral-associated $\mathrm{N}_{2} \mathrm{O}$ emission by humans is $0.00013 \mathrm{Tg} \mathrm{N} / \mathrm{a}$, representing an insignificant amount of $0.0008 \%$ of the total, annual $\mathrm{N}_{2} \mathrm{O}$ emission of $16.4 \mathrm{Tg} \mathrm{N} / \mathrm{a}$ to the atmosphere [48]. 
Dental biofilms were the main sites of $\mathrm{N}_{2} \mathrm{O}$ production in the human mouth. This result and the microsensor data strongly suggest that dental plaque is also the main site for oral formation of the other denitrification intermediates $\mathrm{NO}_{2}{ }^{-}$and $\mathrm{NO}$. Thus, $\mathrm{NO}_{2}{ }^{-}$measurements in saliva $[20,21]$ are not an adequate proxy for NO formation by human host cells in the mouth (Figure 5). Moreover, plaque denitrification needs to be considered when using $\mathrm{NO}$ and $\mathrm{NO}_{2}^{-}$measurements in breath and saliva to diagnose systemic diseases, such as renal failure $[49,50]$ and cystic fibrosis [51]. More generally, the importance of dental plaque for the formation of denitrification intermediates as compared to other oral surfaces indicates that plaque bacteria are as important for oral nitrogen conversions than bacteria located on other oral surfaces [17]. Consequently, dental biofilms and salivary $\mathrm{NO}_{3}{ }^{-}$concentrations play a crucial role in the regulation of body $\mathrm{NO}_{2}{ }^{-}$concentration and affect $\mathrm{NO}_{2}{ }^{-}$related physiological functions in the human body, such as hypoxic vasodilatation and antimicrobial activity in the acidic stomach (Figure 5, grey lines) [8].

Numerous anatomical sites, including the skin, mouth, stomach, colon, and vagina, are inhabited by distinct microbial communities, which are characterised by a large diversity. This suggests a versatile potential of different metabolic pathways mediated by micro-organisms that affect human physiology. However, activities or the functional potentials of complex human-associated microbial communities have rarely been investigated [1]. Thus, we anticipate that investigations of human-associated microbial communities with techniques that measure their in situ activities will lead to the discovery of unexpected functions and interactions between microbes and humans if expanded to elemental cycles of carbon, sulfur, iron and others. The microbial ecology toolbox available for these experiments comprises techniques, such as microsensors, and isotopic or radioactive labelling with detection in bulk medium and on a single cell level, all of which can be combined with phylogenetic identification [52-55]. This ecophysiological approach will allow the direct testing of hypotheses that emerge from metagenomic data that is generated in the context of the human microbiome project [56].

\section{Conclusions}

Human dental plaque mediates denitrification based on salivary $\mathrm{NO}_{3}{ }^{-}$. Plaque denitrification is performed under aerobic conditions and leads to biological and chemical $\mathrm{NO}$ and $\mathrm{N}_{2} \mathrm{O}$ formation in a $\mathrm{pH}$-dependent manner. Plaque $\mathrm{O}_{2}$ uptake is inhibited by NO. Thus, formation of $\mathrm{NO}$ mediates metabolic interactions between plaque bacteria. Moreover, NO is produced at concentration levels that allow signalling to human host cells, pointing toward a significant role in the regulation of inflammatory disorders of gum tissue (that is, periodontal diseases). Microbial denitrification is, besides NO synthase activity and acidic decomposition of $\mathrm{NO}_{2}^{-}$, an alternative pathway of NO formation in humans. Denitrification in dental plaque is a relevant site for production of intermediates of nitrogen cycling in the human mouth and is dependent on salivary $\mathrm{NO}_{3}{ }^{-}$. Thus, breath analysis for the detection of systemic diseases should consider plaque activity, and denitrification in dental plaque may affect the physiology of the whole human body.

\section{Methods}

\section{Samples}

Samples of natural, dental plaque were obtained with toothpicks or dental floss from male and female volunteers ( 25 to 52 years in age), who had not taken antibiotics, and not being diagnosed as having periodontitis and/or other severe diseases. Experiments involving human samples were approved by the Federal Dentists Chamber Bremen (Landeszahnärztekammer Bremen, Germany) and all volunteers gave their written consent.

\section{$\mathrm{N} 2$ production from isotopically-labelled $\mathrm{NO}_{3}{ }^{-}$}

Dental biofilms were collected with a toothpick from dental surfaces and interproximal (IP) spaces of three volunteers and were washed twice in phosphate-buffered saline (PBS; $\mathrm{pH}$ 7.2). The protein content of the sample was determined after Lowry [57]. Biofilms were homogenised by vortexing, the material of each individual was equally distributed to three exetainers $(3.8 \mathrm{ml})$ and filled with air saturated incubation medium (phosphate buffered saline and $2 \%$ sucrose). The incubation was immediately started by adding $50 \mu \mathrm{M} \mathrm{Na}{ }^{15} \mathrm{NO}_{3}$ and was performed under continuous mixing at $37^{\circ} \mathrm{C}$. Dissolved $\mathrm{O}_{2}$ concentration was measured with an $\mathrm{O}_{2}$ microsensor, directly before biological reactions were stopped by adding $\mathrm{ZnCl}_{2}$ to a final concentration of $0.5 \%$ at three time points $\left(\mathrm{t}_{0}=0 \mathrm{~h} ; \mathrm{t}_{1}=3.5 \mathrm{~h} ; \mathrm{t}_{2}=5 \mathrm{~h}\right)$. A quadrupole mass spectrometer (GAM 200, IP Instruments, Bremen, Germany) was used to measure ${ }^{30} \mathrm{~N}_{2}$ after introducing a $2 \mathrm{ml}$ helium headspace into the closed exetainer and equilibration between the liquid and gas phase.

\section{Microsensor measurements}

Plaque from two volunteers was subjected to in situ measurements with $\mathrm{NO}, \mathrm{N}_{2} \mathrm{O}, \mathrm{O}_{2}, \mathrm{pH}$ and $\mathrm{NO}_{3}{ }^{-}$microsensors outside the mouth. Biofilms were carefully recovered with toothpicks or dental floss from the IP spaces of the upper or lower molars by volunteers that did not brush their teeth for at least $24 \mathrm{~h}$. Whole biofilm pieces were placed on solid agar (1.5\%), fixed with a drop of molten agar $(0.5 \%)$ and covered with non-buffered sucrose/salt medium (68 mM NaCl, $8 \mathrm{mM} \mathrm{MgCl}_{2}$, 
$3.6 \mathrm{mM} \mathrm{CaCl}_{2}, 26.8 \mathrm{mM} \mathrm{KCl}, 2 \%$ sucrose; $\mathrm{pH} 6.6$ to 7.2). Biofilms equilibrated for at least $20 \mathrm{~min}$ before the measurements, which were performed within 6 to $8 \mathrm{~h}$ after biofilm retrieval. Manufacturing of amperometric $\mathrm{NO}, \mathrm{N}_{2} \mathrm{O}$ and $\mathrm{O}_{2}$, and ion-selective $\mathrm{pH}$ and $\mathrm{NO}_{3}$ microsensors [28,58-60] and microsensor measurements [28] were conducted as previously described. Steady state microprofiles were measured before and after 760 $\mu \mathrm{M} \mathrm{NaNO}$ was added, while an air jet directed on the medium surface created a constant flow regime above the biofilm. To investigate nitrogen cycling at pH 6 to 7 in the biofilm the medium was supplemented with phos-

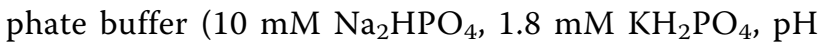
7.2; resembling the concentration in $1 \times \mathrm{PBS})$, thereby excluding chemical $\mathrm{NO}_{2}{ }^{-}$reduction. To increase sensor performance, $\mathrm{NO}_{3}{ }^{-}$microprofiles were measured in medium with lower salt content, and in the presence and absence of $50 \mu \mathrm{M} \mathrm{NaNO}$, instead of $760 \mu \mathrm{M}$. All presented measurements were performed in the same biofilm spot. Thus, the measurements are suitable to draw mechanistic conclusions. However, the data do not account for biofilm heterogeneity and are not suitable for calculation of average fluxes over a given biofilm surface. We repeated the same experiment with a biofilm from a second individual, which essentially showed the same treatment effects (see Additional file 1, Figure S1 and supplementary discussion).

\section{Molecular analysis of denitrification genes from dental biofilms}

Dental plaque was collected from dental surfaces and IP spaces with sterile toothpicks by five volunteers that had not brushed their teeth or eaten for $12 \mathrm{~h}$. DNA was extracted according to a protocol optimised for dental plaque [61]. PCR amplification of partial sequences of the denitrification genes narG, nirS, nirK, cnorB, qnorB, and $\operatorname{nos} Z$ was performed in a total volume of $20 \mu \mathrm{l}$ containing $2 \mu \mathrm{l}$ of $10 \times$ PCR buffer, $250 \mu \mathrm{M}$ of each deoxyribonucleoside triphosphate, $1 \mathrm{U}$ of Taq polymerase (5 Prime GmbH, Hamburg, Germany), $0.3 \mathrm{mg} / \mathrm{ml}$ bovine serum albumin (BSA), $0.5 \mu \mathrm{M}$ of each primer and 10 to 100 ng DNA. Published primers that target a wide spectrum of denitrification genes from different organisms were used and PCR experiments were performed as described in the corresponding protocols with some modifications (Additional file 1, Table S1). Amplicons were analysed by electrophoresis on $1 \%$ agarose gels and subsequent ethidium bromide staining. For 11 out of 22 amplicons with the expected size clone libraries were constructed and sequenced to confirm that PCR products corresponded to the targeted genes. Amplicons were purified with the QIAQuick PCR purification kit (Qiagen, Hilden, Germany) and cloned using the TOPO TA cloning system (Invitrogen, Carlsbad, CA, USA) following the manufacturer's instructions. The obtained sequences were analysed with BLAST http://www.ncbi. nlm.nih.gov. Only 1 of the 11 clone libraries did not contain the targeted gene (nirS, subject D).

\section{$\mathrm{N}_{2} \mathrm{O}$ accumulation in mouth air}

A total of 15 volunteers ( 25 to 52 years in age) were asked not to brush their teeth the night and morning before the measurement. They were allowed to eat and drink, but not during the last hour before the measurements. To exclusively measure $\mathrm{N}_{2} \mathrm{O}$ that is produced in the mouth, but not in the lung or the stomach, we injected ambient air $(30 \mathrm{ml})$ into the empty mouth. Subsequently, volunteers were asked to breathe through the nose with the mouth closed off from the nasopharynx and keep the injected air in their mouth. We defined this air as mouth air in which orally-produced $\mathrm{N}_{2} \mathrm{O}$ accumulated. Two gas samples $(1 \mathrm{ml})$ were withdrawn through the blunt canula of a syringe after 30 and $90 \mathrm{~s}$ and filled into gas-tight exetainers $(3 \mathrm{ml})$. This sampling scheme was repeated five times with teeth unbrushed and five times with teeth brushed by the volunteers. The $\mathrm{N}_{2} \mathrm{O}$ accumulation rate of seven volunteers was additionally measured after both teeth brushing and a 1-min antiseptic mouthwash that contains chlorhexidine, following the package insert (Chlorhexamed fluid, 0.1\%, GlaxoSmithKline, Bühl, Germany). Before brushing the teeth, the volunteers collected $1 \mathrm{ml}$ of saliva that was immediately frozen for later analysis of the $\mathrm{NO}_{3}{ }^{-} / \mathrm{NO}_{2}{ }^{-}$concentration. Subsamples of mouth air were analysed for $\mathrm{N}_{2} \mathrm{O}$ concentration using a gas chromatograph with a ${ }^{63} \mathrm{Ni}$ electron capture detector (Agilent GC7890, Agilent Technologies, Waldbronn, Germany). From the concentration difference between 30 and $90 \mathrm{~s}$ and the incubated volume of air, the rate of $\mathrm{N}_{2} \mathrm{O}$ accumulation was calculated in $\mathrm{nmol} /$ individual/h. The increase of $\mathrm{N}_{2} \mathrm{O}$ concentration in mouth air was shown to be linear for at least $240 \mathrm{~s}$ in additional test runs.

In a separate experiment, the $\mathrm{N}_{2} \mathrm{O}$ accumulation rate of four volunteers with teeth unbrushed was determined before and $2 \mathrm{~h}$ after drinking $200 \mathrm{ml}$ of beetroot juice that contained $12 \mathrm{mM} \mathrm{NO}_{3}^{-}$. The volunteers collected $0.5 \mathrm{ml}$ of saliva before and then hourly after drinking the beetroot juice for later analysis of the $\mathrm{NO}_{3}{ }^{-} / \mathrm{NO}_{2}{ }^{-}$ concentration. Maximum salivary $\mathrm{NO}_{3}{ }^{-}$and $\mathrm{NO}_{2}{ }^{-}$concentrations were generally measured $2 \mathrm{~h}$ after drinking beetroot juice. Saliva samples were cleared by centrifugation and then analysed for $\mathrm{NO}_{3}{ }^{-} / \mathrm{NO}_{2}{ }^{-}$with the $\mathrm{VCl}_{3}$ reduction method [62] followed by $\mathrm{NO}$ measurement on a chemiluminescence detector (CLD 86, EcoPhysics, Duernten, Switzerland).

\section{Data deposition}

Sequences for the denitrification genes obtained in this study have been submitted to the EMBL Nucleotide 
Sequence Database under the accession numbers FN401446 to FN401486

Additional file 1: Supplementary information. Figure S1, discussion of Figure S1, and Table S1.

\section{Acknowledgements}

We thank the volunteers for their participation in the experiments. We thank Angela Schramm for help in sample analysis. We thank Nicole Dubilier, Bo Barker Jørgensen, and Andreas Schramm for valuable comments on the manuscript. This research was supported by the Max Planck Society and Philips Oral Healthcare.

\section{Author details}

'Microsensor Research Group, Max-Planck-Institute for Marine Microbiology, Bremen, Germany. '2Laboratory of Microbial Ecology and Technology (LabMET), Ghent University, Ghent, Belgium. ${ }^{3}$ Center for Genomic Sciences, Allegheny General Hospital/Allegheny-Singer Research Institute, Pittsburgh, PA, USA. ${ }^{4}$ National Centre for Advanced Tribology at Southampton (nCATS), School of Engineering Sciences, University of Southampton, Southampton, UK.

\section{Authors' contributions}

PSto, AG and DdB initiated the study, performed initial microsensor measurements and formulated, together with $\mathrm{W}$, a conceptual framework for nitrate conversions in dental plaque. Microsensor measurements were designed by PSto and FS, and performed and analysed by FS. Isotopic labelling was designed, performed and analysed by PSti and FS. Experiments for oral $\mathrm{N}_{2} \mathrm{O}$ emission were designed by PSti and FS, and performed and analysed by PSti. Molecular analysis of dental plaque was performed by AG and $\mathrm{HH}$, and analysed by $\mathrm{H}$ and PSti. PSti and FS wrote the manuscript with input from PSto and DdB.

Received: 22 December 2009 Accepted: 22 March 2010

Published: 22 March 2010

\section{References}

1. Dethlefsen L, McFall-Ngai M, Relman DA: An ecological and evolutionary perspective on human-microbe mutualism and disease. Nature 2007, 449(7164):811-818

2. Vianna ME, Holtgraewe S, Seyfarth I, Conrads G, Horz HP: Quantitative analysis of three hydrogenotrophic microbial groups, methanogenic archaea, sulfate-reducing bacteria, and acetogenic bacteria, within plaque biofilms associated with human periodontal disease. J Bacteriol 2008, 190(10):3779-3785.

3. Lepp PW, Brinig MM, Ouverney CC, Palm K, Armitage GC, Relman DA Methanogenic Archaea and human periodontal disease. Proc Natl Acad Sci USA 2004, 101(16):6176-6181.

4. Gibson GR, Cummings JH, Macfarlane GT, Allison C, Segal I, Vorster HH, Walker ARP: Alternative Pathways for Hydrogen Disposal During Fermentation in the Human Colon. Gut 1990, 31(6):679-683.

5. Egert M, de Graaf AA, Smidt H, de Vos WM, Venema K: Beyond diversity: functional microbiomics of the human colon. Trends Microbiol 2006, 14(2):86-91.

6. Zumft WG: Cell biology and molecular basis of denitrification. Microbiol Mol Biol Rev 1997, 61(4):533.

7. Lundberg JO, Weitzberg E, Cole JA, Benjamin N: Opinion - Nitrate, bacteria and human health. Nat Rev Microbiol 2004, 2(7):593-602.

8. Lundberg JO, Weitzberg E, Gladwin MT: The nitrate-nitrite-nitric oxide pathway in physiology and therapeutics. Nat Rev Drug Discov 2008, 7(2):156-167.

9. Straub KL, Benz M, Schink B, Widdel F: Anaerobic, nitrate-dependent microbial oxidation of ferrous iron. Appl Environ Microbiol 1996, 62(4):1458-1460
10. Baumann B, Snozzi M, Zehnder AJB, vanderMeer JR: Dynamics of denitrification activity of Paracoccus denitrificans in continuous culture during aerobic-anaerobic changes. J Bacteriol 1996, 178(15):4367-4374.

11. Goretski J, Zafiriou OC, Hollocher TC: Steady-State Nitric-Oxide Concentrations During Denitrification. J Biol Chem 1990, 265(20):11535-11538

12. Conrad R: Soil Microbial Processes and the Cycling of Atmospheric Trace Gases. Philos Trans R Soc Lond Ser A-Math Phys Eng Sci 1995, 351(1696):219-230

13. Schreiber F, Loeffler B, Polerecky L, Kuypers MMM, de Beer D: Mechanisms of transient nitric oxide and nitrous oxide production in a complex biofilm. Isme J 2009, 3(11):1301-1313

14. Stief $P$, Poulsen M, Nielsen LP, Brix H, Schramm A: Nitrous oxide emission by aquatic macrofauna. Proc Natl Acad Sci USA 2009, 106(11):4296-4300

15. Horn MA, Schramm A, Drake HL: The earthworm gut: An ideal habitat for ingested N2O-producing microorganisms. Appl Environ Microbiol 2003, 69(3):1662-1669

16. Kolenbrander PE, Andersen RN, Blehert DS, Egland PG, Foster JS, Palmer RJ: Communication among oral bacteria. Microbiol Mol Biol Rev 2002, 66(3):486.

17. Doel JJ, Benjamin N, Hector MP, Rogers M, Allaker RP: Evaluation of bacterial nitrate reduction in the human oral cavity. Eur J Oral Sci 2005, 113(1):14-19.

18. Duncan C, Dougall H, Johnston P, Green S, Brogan R, Leifert C, Smith L, Golden M, Benjamin N: Chemical Generation of Nitric-Oxide in the Mouth from the Enterosalivary Circulation of Dietary Nitrate. Nat Med 1995, 1(6):546-551.

19. Bayindir YZ, Polat MF, Seven N: Nitric oxide concentrations in saliva and dental plaque in relation to caries experience and oral hygiene. Caries Research 2005, 39(2):130-133.

20. Carossa S, Pera P, Doglio P, Lombardo S, Colagrande P, Brussino L, Rolla G, Bucca C: Oral nitric oxide during plaque deposition. Eur J Clin Invest 2001, 31(10):876-879.

21. Aurer A, Aleksic J, Ivic-Kardum M, Aurer J, Culo F: Nitric oxide synthesis is decreased in periodontitis. J Clin Periodontol 2001, 28(6):565-568.

22. Selwitz RH, Ismail Al, Pitts NB: Dental caries. Lancet 2007, 369(9555):51-59.

23. Pihlstrom BL, Michalowicz BS, Johnson NW: Periodontal diseases. Lancet 2005, 366(9499):1809-1820

24. Kendall HK, Marshall Rl, Bartold PM: Nitric oxide and tissue destruction. Oral Dis 2001, 7(1):2-10

25. Brennan PA, Thomas GJ, Langdon JD: The role of nitric oxide in oral diseases. Arch Oral Biol 2003, 48(2):93-100.

26. Bogdan C: Nitric oxide and the immune response. Nat Immunol 2001, 2(10):907-916

27. Ugar-Cankal D, Ozmeric N: A multifaceted molecule, nitric oxide in oral and periodontal diseases. Clin Chim Acta 2006, 366(1-2):90-100

28. Schreiber F, Polerecky L, de Beer D: Nitric oxide microsensor for high spatial resolution measurements in biofilms and sediments. Anal Chem 2008, 80(4):1152-1158.

29. Cooper CE: Nitric oxide and cytochrome oxidase: substrate, inhibitor or effector? Trends BiochemSci 2002, 27(1):33-39.

30. Stevanin TM, loannidis N, Mills CE, Kim SO, Hughes MN, Poole RK: Flavohemoglobin $\mathrm{hmp}$ affords inducible protection for Escherichia coli respiration, catalyzed by cytochromes bo ' or bd, from nitric oxide. J Biol Chem 2000, 275(46):35868-35875.

31. Parham NJ, Gibson GR: Microbes involved in dissimilatory nitrate reduction in the human large intestine. FEMS Microbiol Ecol 2000, 31(1):21-28.

32. Mohan SB, Cole JA: The Dissimilatory Reduction of Nitrate to Ammonia by Anaerobic Bacteria. The Biology of the Nitrogen Cycle Amsterdam: ElsevierBothe H, Ferguson SJ, Newton WE , 12007.

33. Lam P, Lavik G, Jensen MM, Vossenberg van de J, Schmid M, Woebken D, Dimitri G, Amann $R$, Jetten MSM, Kuypers MMM: Revising the nitrogen cycle in the Peruvian oxygen minimum zone. Proc Natl Acad Sci USA 2009, 106(12):4752-4757.

34. Hall-Stoodley L, Costerton JW, Stoodley P: Bacterial biofilms: From the natural environment to infectious diseases. Nat Rev Microbiol 2004, 2(2):95-108.

35. Visek WJ: Diet and Cell-Growth Modulation by Ammonia. Am J Clin Nutr 1978, 31(10):S216-S220. 
36. Lloyd D: Aerobic Denitrification in Soils and Sediments - from Fallacies to Facts. Trends Ecol Evol 1993, 8(10):352-356.

37. Gao H, Schreiber F, Collins G, Jensen MM, Kostka JE, Lavik G, de Beer D, Zhou H-y, Kuypers MMM: Aerobic denitrification in permeable Wadden Sea sediments. ISME J 2009.

38. Robertson LA, Kuenen JG: Aerobic Denitrification - a Controversy Revived. Arch Microbiol 1984, 139(4):351-354.

39. Zumft WG: Nitric oxide reductases of prokaryotes with emphasis on the respiratory, heme-copper oxidase type. J Inorg Biochem 2005, 99(1):194-215.

40. Barraud N, Hassett DJ, Hwang SH, Rice SA, Kjelleberg S, Webb JS: Involvement of nitric oxide in biofilm dispersal of Pseudomonas aeruginosa. J Bacterio/ 2006, 188(21):7344-7353.

41. Marsh PD: Are dental diseases examples of ecological catastrophes? Microbiology-(UK) 2003, 149:279-294

42. Bedioui $\mathrm{F}$, Villeneuve N: Electrochemical nitric oxide sensors for biological samples - Principle, selected examples and applications. Electroanalysis 2003, 15(1):5-18.

43. Chen K, Pittman RN, Popel AS: Nitric oxide in the vasculature: Where does it come from and where does it go? A quantitative perspective. Antioxid Redox Signal 2008, 10(7):1185-1198.

44. Russow R, Neue HU, Wolf I, Plath C: Humans as a source of N2O Evidences from breath air analysis and $\mathrm{N}-15$ tracer experiments. 3rd International Symposium on Non-CO2 Greenhouse Gases: Jan 21-23 2002; Maastricht, Netherlands Millpress Science Publishers 2002, 155-156.

45. Mitsui $\mathrm{T}$, Kondo T: Effects of mouth cleansing on the levels of exhaled nitrous oxide in young and older adults. Sci Total Environ 1998, 224(13):177-180.

46. Bleakley BH, Tiedje JM: Nitrous-Oxide Production by Organisms Other Than Nitrifiers or Denitrifiers. Appl Environ Microbiol 1982, 44(6):1342-1348.

47. Crutzen PJ: Role of No and No2 in the Chemistry of the Troposphere and Stratosphere. Annu Rev Earth Planet Sci 1979, 7:443-472.

48. IPCC: Climate Change 2001: The Scientific Basis. IPCC Third Assessment Report Climate Change 2001

49. Rolla G, Bruno M, Bommarito L, Heffler E, Ferrero N, Petrarulo M, Bagnis C, Bugiani M, Guida G: Breath analysis in patients with end-stage renal disease: effect of haemodialysis. Eur J Clin Invest 2008, 38(10):728-733.

50. Matsumoto A, Hirata Y, Kakoki M, Nagata D, Momomura S, Sugimoto T, Tagawa H, Omata M: Increased excretion of nitric oxide in exhaled air of patients with chronic renal failure. Clin Sci 1999, 96(1):67-74

51. Zetterquist W, Marteus H, Kalm-Stephens P, Nas E, Nordvall L, Johannesson M, Alving K: Oral bacteria - The missing link to ambiguous findings of exhaled nitrogen oxides in cystic fibrosis. Respir Med 2009, 103(2):187-193.

52. Lee N, Nielsen $\mathrm{PH}$, Andreasen $\mathrm{KH}$, Juretschko S, Nielsen JL, Schleifer $\mathrm{KH}$ Wagner M: Combination of fluorescent in situ hybridization and microautoradiography - a new tool for structure-function analyses in microbial ecology. Appl Environ Microbiol 1999, 65(3):1289-1297.

53. Behrens S, Losekann T, Pett-Ridge J, Weber PK, Ng WO, Stevenson BS, Hutcheon ID, Relman DA, Spormann AM: Linking microbial phylogeny to metabolic activity at the single-cell level by using enhanced element labeling-catalyzed reporter deposition fluorescence in situ hybridization (EL-FISH) and NanoSIMS. Appl Environ Microbiol 2008, 74(10):3143-3150.

54. Schramm A: In situ analysis of structure and activity of the nitrifying community in biofilms, aggregates, and sediments. Geomicrobiol J 2003, 20(4):313-333.

55. Kuypers MM, Jorgensen BB: The future of single-cell environmental microbiology. Environ Microbiol 2007, 9(1):6-7.

56. Turnbaugh PJ, Ley RE, Hamady M, Fraser-Liggett CM, Knight R, Gordon Jl: The Human Microbiome Project. Nature 2007, 449(7164):804-810.

57. Lowry OH, Rosebrough NJ, Farr AL, Randall RJ: Protein Measurement with the Folin Phenol Reagent. J Biol Chem 1951, 193(1):265-275.

58. Andersen K, Kjaer T, Revsbech NP: An oxygen insensitive microsensor for nitrous oxide. Sens Actuator B-Chem 2001, 81(1):42-48.

59. Revsbech NP: An Oxygen Microsensor with a Guard Cathode. Limnol Oceanogr 1989, 34(2):474-478.

60. deBeer D, Schramm A, Santegoeds CM, Kuhl M: A nitrite microsensor for profiling environmental biofilms. Appl Environ Microbiol 1997, 63(3):973-977

61. Parrish KD, Greenberg EP: A Rapid Method for Extraction and Purification of DNA from Dental Plaque. Appl Environ Microbiol 1995, 61(11):4120-4123.
62. Braman RS, Hendrix SA: Nanogram Nitrite and Nitrate Determination in Environmental and Biological-Materials by Vanadium(lii) Reduction with Chemi-Luminescence Detection. Anal Chem 1989, 61(24):2715-2718.

doi:10.1186/1741-7007-8-24

Cite this article as: Schreiber et al: Denitrification in human dental plaque. BMC Biology 2010 8:24

\section{Submit your next manuscript to BioMed Central and take full advantage of:}

- Convenient online submission

- Thorough peer review

- No space constraints or color figure charges

- Immediate publication on acceptance

- Inclusion in PubMed, CAS, Scopus and Google Scholar

- Research which is freely available for redistribution
C Biomed Central 